\title{
Characteristics of Postpartum Hemorrhage Patients in Raja Tombolotutu General Hospital, Parigi Moutong Sulawesi Tengah, Indonesia
}

\author{
Arnova Reswari, ${ }^{1}$ Willy Akbar, ${ }^{1}$ Eppy Darmadi Achmad ${ }^{2}$ \\ ${ }^{1}$ Raja Tombolotutu General Hospital, Parigi Moutong Sulawesi Tengah Indonesia \\ ${ }^{2}$ Department of Obstetric and Gynecology, Faculty of Medicine Padjadjaran University, \\ Hasan Sadikin General Hospital, Bandung \\ Korespondensi: Arnova Rewari, Email: arnovareswari.fkunpad@gmail.com
}

\begin{abstract}
Objective: This study aimed to identify the characteristics of postpartum hemorrhage patients in Raja Tombolotutu General Hospital, Parigi Moutong Sulawesi Tengah Indonesia.

Method: A retrospective-descriptive study was conducted using a cross-sectional method and secondary data with total sampling technique from medical record of obstetric patients with postpartum hemorrhage in Raja Tombolotutu General Hospital, from May 2017 to April 2018.

Result: From 72 cases of postpartum hemorrhage, patients' characteristics were age 20-35 years old (56.95\%), multipara (45.84\%), gestational age 37-42 weeks (69.45\%), underwent vaginal delivery (93.05\%), junior high school graduated (41.67\%), housewife (59.72\%), delivered in Primary Health Care (59.72\%) and covered by Universal Health Coverage (58.33\%). About $54.17 \%$ patients of postpartum hemorrhage have done $1-4$ times for antenatal care visits. Majority etiology of the postpartum hemorrhage was retained placenta (61.11\%). Conclusion: The major characteristics of postpartum hemorrhage patients are 20-35 years old, multipara, at term pregnancy, underwent vaginal delivery, junior high school graduated, and housewife. Most of them delivered in Primary Health Care and covered by Universal Health Coverage. Retained placenta is the main cause of postpartum hemorrhage. More than half of postpartum hemorrhage patients have done 1-4 times antenatal care visits.
\end{abstract}

Key words: postpartum hemorrhage, maternal mortality, retained placenta

\section{Karakteristik Pasien Perdarahan Postpartum di RSUD Raja Tombolotutu Kabupaten Parigi Moutong Sulawesi Tengah, Indonesia}

\begin{abstract}
Abstrak
Tujuan: Penelitian ini bertujuan untuk menggambarkan karakteristik pasien perdarahan postpartum di RSUD Raja Tombolotutu, Kabupaten Parigi Moutong Sulawesi Tengah Indonesia.

Metode: Penelitian ini merupakan penelitian deskriptif retrospektif yang menggunakan metode potong lintang dan data sekunder dengan teknik total sampling dari rekam medis pasien dengan diagnosis perdarahan postpartum di RSUD Raja Tombolotutu, mulai Mei 2017 sampai April 2018.

Hasil: Dari 72 kasus perdarahan postpartum, karakteristik pasien antara lain: usia 20-35 tahun (56,95\%), multipara (45,84\%), usia kehamilan 37-42 minggu (69,45\%), persalinan pervaginam $(93,05 \%)$, lulusan sekolah menengah pertama $(41,67 \%)$, ibu rumah tangga $(59,72 \%)$, bersalin di puskesmas $(59,72 \%)$ dan pembiayaan ditanggung oleh Jaminan Kesehatan Nasional (58,33\%). Etiologi perdarahan postpartum terbanyak adalah retensio plasenta (61,11\%). Sebanyak 54,17\% pasien perdarahan postpartum pernah melakukan 1-4 kali kunjungan antenatal.

Kesimpulan: Karakteristik pasien perdarahan postpartum yang tertinggi adalah pasien dengan usia 20-35 tahun, multipara, kehamilan aterm, persalinan pervaginam, lulusan sekolah menengah pertama, dan ibu rumah tangga. Sebagian besar pasien bersalin di puskesmas dan pembiayaan ditanggung oleh Jaminan Kesehatan Nasional. Retensio plasenta merupakan penyebab utama perdarahan postpartum. Sebanyak lebih dari setengah pasien perdarahan postpartum pernah melakukan 1-4 kali kunjungan antenatal.
\end{abstract}

Kata kunci: perdarahan postpartum, kematian ibu, retensio plasenta 


\section{Introduction}

Indonesia is the second highest country in maternal mortality rates among Southeast Asia region. According to ASEAN Statistical Report on Millennium Development Goal 2017, the maternal mortality rate (MMR) of Indonesia was 305 per 100,000 live births in 2015. For comparison, in 2015, the MMR in Singapore was 7 per 100,000 live births and the MMR in Malaysia was 24 per 100,000 live births. ${ }^{1}$ The MMR of Indonesia had decreased from 2012 to 2015. However, it is still far from the Sustainable Development Goal target of less than 70 maternal deaths per 100,000 live births in 2030. ${ }^{2}$ The MMR of Sulawesi Tengah is the fourth highest in Indonesia, following Maluku Utara as the highest, Sulawesi Barat as the second highest, and Papua Barat as the third highest. In 2015, the MMR of Sulawesi Tengah was 311 per 100,000 live births. Parigi Moutong is one of the regency of Sulawesi Tengah that has high number of maternal mortality. Based on Health Profile of Sulawesi Tengah 2015, Parigi Moutong had 13 cases of maternal mortality. The cases of maternal mortality in Parigi Moutong was steadily increased. By the end of 2016, 18 cases were discovered. There are three main causes of maternal mortality in Parigi Moutong, which are hemorrhage (35.61\%), hypertension $(18.18 \%)$ and infection $(8.33 \%){ }^{3}$

Postpartum hemorrhage

(PPH)

remains the leading cause of maternal mortality and morbidity in developing countries, ${ }^{4}$ particularly in Indonesia. PPH is most commonly observed in regions with inadequate access to health services, poor nutrition, and anemia. ${ }^{5-7}$ Although the incidence of $\mathrm{PPH}$ tends to decrease years after years, it remains a big challenge in rural area with limited resources.

Definition of PPH is a blood loss of 500 $\mathrm{ml}$ or more from genital tract after vaginal delivery or a blood loss of $1000 \mathrm{ml}$ or more after cesarean delivery. It consists of minor hemorrhage (500-1000 $\mathrm{mL})$ and major hemorrhage $(>1000 \mathrm{~mL}){ }^{8,9}$ The frequent etiologies of PPH are due to uterine atony with bleeding from the placental implantation site (tone), genital tract trauma (trauma), retained placenta or blood clot that leads inadequate uterus contraction (tissue), and coagulation problem (thrombin). ${ }^{9-11}$ Severe maternal morbidity caused by PPH includes shock, respiratory distress syndrom, coagulopathy, loss of fertility, and Sheehan syndrome. ${ }^{12}$

Three cases of maternal mortality were occured in Raja Tombolotutu General Hospital, Parigi Moutong Sulawesi Tengah from May 2017 to April 2018. Postpartum hemorrhage was also one of the main obstetric cases in this hospital. There were 72 cases in the same period. In order to decrease the maternal mortality in Parigi Moutong, the objectives of this study was to identify the characteristics of postpartum hemorrhage patients in Raja Tombolotutu General Hospital, Parigi Moutong Sulawesi Tengah.

\section{Method}

A retrospective-descriptive study was carried out using a cross-sectional method and secondary data with total sampling technique. The data obtained from medical record of obstetric patients with postpartum hemorrhage in Raja Tombolotutu General Hospital, from May 2017 to April 2018. The variables of this study were maternal age, parity, gestational age, mode of delivery, education, occupation, mode of payment, place of delivery, etiology of PPH and antenatal care. The data was tabulated and analyzed using Microsoft Excel 2010 and presented in tables.

\section{Result}

The data obtained from medical record of obstetric patients in Raja Tombolotutu 
Table 1 Characteristic of Patients with Postpartum Hemorrhage

\begin{tabular}{|c|c|c|c|}
\hline & Characteristic of patients & $\begin{array}{l}\text { Frequency } \\
\text { (n) }\end{array}$ & $\begin{array}{c}\text { Percentage } \\
(\%)\end{array}$ \\
\hline \multirow[t]{3}{*}{ Maternal age } & $<20 \mathrm{yr}$ & 16 & 22.22 \\
\hline & $20-35 \mathrm{yr}$. & 41 & 56.95 \\
\hline & $>35 \mathrm{yr}$ & 15 & 20.83 \\
\hline \multirow[t]{4}{*}{ Parity } & Nullipara & 7 & 9.72 \\
\hline & Primipara & 16 & 22.22 \\
\hline & Multipara & 33 & 45.84 \\
\hline & Grande multipara & 16 & 22.22 \\
\hline \multirow[t]{3}{*}{ Gestational Age } & $<37$ week & 9 & 12.50 \\
\hline & $37-42$ week & 50 & 69.45 \\
\hline & $>42$ week & 13 & 18.05 \\
\hline \multirow[t]{2}{*}{ Delivery } & Vaginal delivery & 67 & 93.05 \\
\hline & Cesarean delivery & 5 & 6.95 \\
\hline \multirow[t]{5}{*}{ Education } & None & 11 & 15.28 \\
\hline & Elementary school & 23 & 31.94 \\
\hline & Junior high school & 30 & 41.67 \\
\hline & Senior high school & 5 & 6.94 \\
\hline & College & 3 & 4.17 \\
\hline \multirow[t]{4}{*}{ Occupation } & Housewife & 43 & 59.72 \\
\hline & Seller & 18 & 25.00 \\
\hline & Household assistant & 8 & 11.12 \\
\hline & Private employee & 3 & 4.16 \\
\hline \multirow[t]{3}{*}{ Mode of payment } & $\begin{array}{l}\text { Universal Health Coverage } \\
(\mathrm{JKN})\end{array}$ & 42 & 58.33 \\
\hline & JAMPERSAL & 18 & 25.00 \\
\hline & Self-pay & 12 & 16.67 \\
\hline \multirow[t]{2}{*}{ Place of delivery } & Primary Health Care & 43 & 59.72 \\
\hline & Home (without health providers) & 29 & 40.28 \\
\hline
\end{tabular}

General Hospital from May 2017 to April 2018 revealed 72 cases of postpartum hemorrhage and three of them contributed to maternal mortality $(4.16 \%)$. The characteristics of these patients were shown in Table 1 .

The majority of patients with PPH were $20-35$ years old $(56.95 \%)$. About $45.84 \%$ was multipara and about $69.45 \%$ patients were at term pregnancy (37-42 week of gestational age). Almost all of the patients with $\mathrm{PPH}$ underwent vaginal delivery (93.05\%). More than half of patients were housewife, and about $41.67 \%$ was graduated from junior high school. The patients with PPH delivered in Primary Health Care (59.72\%) and also more than $50 \%$ patient was covered by Universal Health Coverage.

Most of the cause of PPH was retained placenta (61.11\%), followed by placental remnant, genital tract laceration, and uterine atony. There was no uterine rupture case. (Table 2)

Most patients with $\mathrm{PPH}$ underwent 1-4x 
Table 2 Etiology of Postpartum Hemorrhage

\begin{tabular}{lcc}
\hline \multicolumn{1}{c}{ Etiology of PPH } & $\begin{array}{c}\text { Frequency } \\
\text { (n) }\end{array}$ & $\begin{array}{c}\text { Percentage } \\
(\mathbf{\%})\end{array}$ \\
\hline Uterine atony & 5 & 6.95 \\
Genital tract laceration & 7 & 9.72 \\
Placental remnant & 16 & 22.22 \\
Retained placenta & 44 & 61.11 \\
\hline
\end{tabular}

Table 3 Antenatal Care of Patients with Postpartum Hemorrhage

\begin{tabular}{lcc}
\hline $\begin{array}{c}\text { Antenatal Care } \\
\text { (ANC) }\end{array}$ & $\begin{array}{c}\text { Frequency } \\
\text { (n) }\end{array}$ & $\begin{array}{c}\text { Percentage } \\
\text { (\%) }\end{array}$ \\
\hline None & 18 & 25.00 \\
$1-4 \mathrm{x}$ & 39 & 54.17 \\
$>4 \mathrm{x}$ & 15 & 20.83 \\
\hline
\end{tabular}

antenatal care visits (54.17\%). However, about $25 \%$ patients had never done antenatal care. (Table 3)

\section{Discussion}

The highest maternal morbidity etiology is postpartum hemorrhage and occurs in association with several identifiable patient characteristics. ${ }^{13}$ Maternal age $\geq 35$ years old have been reported as a significant risk factor of PPH. ${ }^{14,15}$ However, the study by Durmaz et al revealed that no relationship between maternal age $\geq 35$ years old and PPH. ${ }^{5}$ This study discovered that maternal age with the highest percentage was 20-35 years old $(57.5 \%)$. Previous study by Driessen et al had the same result that the highest women with PPH is $20-35$ years old. ${ }^{16}$ Other study by Londok et al showed that postpartum hemorrhage participants $\geq 35$ years old were the highest percentage. ${ }^{17}$

This study discovered that multipara patients were dominant, which was $45.84 \%$. Contrary to this study, the previous studies revealed that primiparity is one of risk factors for PPH. ${ }^{5,16,18}$ About $69.45 \%$ of PPH occurred to the patient with gestational age 37-42 weeks (term pregnancy). This study showed the same result with two previous studies that found most of the women with PPH is in 3742 weeks pregnancy. ${ }^{16,17}$ This study showed that most of patients with PPH were resulted from vaginal delivery $(93.05 \%)$. The previous study had the same result with this study. ${ }^{17}$ Study by Kramer et al, however, showed that cesarean delivery is one of risk factor for PPH. There were $41.67 \%$ junior high school graduated of post partum hemorrhage patients and about $15.28 \%$ never have formal education. Culture, lack of education, and decision-making power conspire to limit access to an ideal environment for pregnancy and childbirth. Education also plays an important role that could influence knowledge and attitude of someone toward health problems, the poor knowledge will lead to negative attitude. ${ }^{7}$

This study was in line with the study conducted by Londok et al that most of the patients with PPH are housewife (59.72\%). ${ }^{17}$ More than a half of patients with $\mathrm{PPH}$ were covered by Universal Health Coverage $(58.33 \%)$. In addition, $25 \%$ patients were covered by Jampersal. This is one of government efforts for decreasing maternal mortality rate by facility easy access health care with affordable cost. 
In this study, the patient with $\mathrm{PPH}$ delivered in Primary Health Care was $59.72 \%$. The coverage of health-providerassisted-delivery in Sulawesi Tengah tends to decline every year. In 2015, the coverage was $74 \%$ that did not achieve the goal of Rencana Strategis Kementrian Kesehatan, which was $90 \%$. This study represented the poor coverage of health-provider-assisteddelivery in Parigi Moutong, which was $61.01 \%$ in 2015 . Health-provider-assisteddelivery have been proven in decreasing the maternal mortality rate. ${ }^{3}$ However, this study showed about $40.28 \%$ delivery had carried out at home and assisted by traditional birth attendant. The fact was an irony, due to government of Sulawesi Tengah had tried to decrease the number of maternal mortality by some programs, such as Kemitraan Bidan dan Dukun and Rumah Tunggu Kelahiran to facilitate health-provider-assisteddelivery. ${ }^{3}$ It still became a big challenge to perform that program due to community belief and tradition. Some pregnant women believed that traditional birth attendant have hereditary knowledge from the ancestor and great experience in vaginal delivery. Beside of the affordable cost, "jampi-jampi" also one of the reasons, it makes pregnant women feel comfortable and treat them with love. ${ }^{19}$

The main cause of PPH in this study was retained placenta $(61.11 \%)$. It was different from theory that the most $\mathrm{PPH}$ is due to uterine atony. ${ }^{16,20}$ Two previous studies showed the same result that retained placenta is a risk factor that strongly associated with PPH. ${ }^{21}$ Study by Londok et al showed the second highest percentage for the cause of PPH was retained placenta, following the placental remnant. ${ }^{17}$

Antenatal care (ANC) and delivery care by skilled attendants are recommended to improve maternal health. ${ }^{22}$ According to WHO recommendation, the pregnant women at least do 8 times of ANC visits. The definition of ANC is the routine care of pregnant women provided between conception and the onset of labor. ${ }^{23}$ In accordance with the WHO recommendation, there was only $20.83 \%$ patients with PPH had done $\geq 4$ times of ANC visits. The ANC visit of Sulawesi Tengah was steadily decreased from 2012 to 2015. The number of $\mathrm{K} 4$ is the coverage of pregnant women had received ANC according to the standard at least 4 times in one area at a certain time period. The number of $\mathrm{K} 4$ in Parigi Moutong did not achieve the goal of Rencana Strategis Kementrian Kesehatan. ${ }^{3}$ The previous study also showed that most of the patients with PPH did not do minimum of 8 ANC visits. ${ }^{17}$ Study by Thida et al concluded that utilization and expectation of community-based ANC services and facility delivery is also low in another developing country. ${ }^{22}$

This study concluded that the most characteristic of $\mathrm{PPH}$ patients were that 2035 years old, multipara, at term pregnancy, underwent vaginal delivery, junior high school graduated, and housewife. Most of them delivered in Primary Health Care and covered by Universal Health Coverage. Retained placenta is the main cause of PPH. More than half of $\mathrm{PPH}$ patients have done 1-4 times ANC visits.

This study has confronted several limitations. Firstly, the researcher used secondary data from medical records and did not directly involve in data collection. Secondly, this was a cross-sectional study. Thirdly, total sampling used in this study due to small sample size. Fourthly, this study focused to characteristics patients in general hospital with limited resources settings, therefore, generalization of the findings throughout Indonesia cannot be made. Last, body mass index and patient's delivery history were not measured in this study.

This study hopefully can give information about characteristic of $\mathrm{PPH}$ patients in Raja Tomboltutu General Hospital and used as formal reference for health-care 
provider to decrease the maternal mortality rate, particularly in Parigi Moutong Sulawesi Tengah. Further study is needed to find out the association between characteristics of patients and risk factor of PPH.

\section{References}

1. ASEAN statistical report on millennium development goal. Jakarta: ASEAN Secretariat; 2017.

2. Profil kesehatan Indonesia tahun 2016. Jakarta: Kementrian Kesehatan Republik Indonesia; 2017.

3. Profil kesehatan provinsi Sulawesi Tengah tahun 2015. Palu: Dinas Kesehatan Provinsi Sulawesi Tengah; 2016.

4. Ononge S, Mirembe F, Wandabwa J, Campbell OM. Incidence and risk factors for postpartum hemorrhage in Uganda. Reprod Health. 2016;13(38).

5. Durmaz A, Komurcu N. Relationship between maternal characteristic and postpartum hemorrhage: a meta-analysis study. J Nurs Res. 2017;26(5):362-72.

6. Prata N, Gessessew A, Abraha AK, Holston M, Potts M. Prevention of postpartum hemorrhage: options for home births in rural Ethiopia. Afr $\mathrm{J}$ Reprod Health. 2009;13(2):87-95.

7. Geller SE, Adams MG, Kelly PJ, Kodkany BS, Derman RJ. Postpartum hemorrhage in resource-poor settings. Int J Gynaecol Obstet 2006;92(3):202-11.

8. Andrikopoulou M, D'Alton ME. Postpartum hemorrhage: early identification challenges. Semin Perinatol. 2018.

9. Oyelese Y, Ananth CV. Postpartum hemorrhage: epidemiology, risk factors, and causes. Clin Obstet Gynecol. 2010;53(1):147-56.

10. Lausman AY, Ellis CAJ, RBeecroft J, Simons M, Shapiro JL. A rare etiology of delayed postpartum hemorrhage. J Obstet Gynecol Can. 2008;30(3):239-43.
11. PracticeBulletin Postpartum Hemorrhage. Obstet Gynecol. 2017;130(4):e168-e86.

12. Koopmans CM, van der Tuuk K, Groen H, Doornbos JP, de Graaf IM, van der Salm PC, et al. Prediction of postpartum hemorrhage in women with gestational hypertension or mild preeclampsia at term. Acta Obstet Gynecol Scand. 2014;93(4):399-407.

13. Grobman WA, Bailit JL, Rice MM, Wapner RJ, Reddy UM, Varner MW, et al. Frequency of and factors associated with severe maternal morbidity. Obstet Gynecol. 2014;123(4):804-10.

14. Kramer MS, Berg C, Abenhaim H, Dahhou M, Rouleau J, Mehrabadi A, et al. Incidence, risk factors, and temporal trends in severe postpartum hemorrhage. Am J Obstet Gynecol. 2013;209(5):449. e1-.e7.

15. Lao TT, Sahota DS, Cheng YKY, Law LW, Leung TY. Advanced maternal age and postpartum hemorrhage - risk factor or red herring? J Matern Fetal Neonatal Med. 2014;27(3):243-6.

16. Driessen M, Bouvier-Colle M-H, Dupont C, Khoshnood B, Rudigoz R-C, DeneuxTharaux C. Postpartum hemorrhage resulting from uterine atony after vaginal delivery: factors associated with severity. Obstet Gynecol. 2011;117(1):21-31.

17. Londok T, Lengkong R, Suparman E. Karakteristik perdarahan antepartum dan Perdarahan postpartum. Jurnal e-Biomedik (eBM). 2013;1(1):614-20.

18. Kramer MS, Dahhou M, Vallerand D, Liston R, Joseph KS. Risk factors for postpartum hemorrhage, can we explain the recent temporal increase? J Obstet Gynaecol Can. 2011;33(8):810-9.

19. Anggorodi R. Dukun Bayi dalam Persalinan oleh Masyarakat Indonesia. Makara Kesehatan. 2009;13(1):9-14.

20. Nyflot LT, Sandven I, Stray-Pedersen B, Pettersen S, Al-Zirqi I, Rosenberg M, et al. Risk factors for severe postpartum 
hemorrhage: a case-control study. BMC pregnancy and childbirth. 2017;17(1):17.

21. Sosa CG, Althabe F, Belizan JM, Buekens P. Risk factor for postpartum hemorrhage in vaginal deliveries in a Latin-American population. Obstet Gynecol. 2009;113(6):1313-9.

22. Thida T, Liabsuetrakul T, McNeil E. Disparity in utilization and expectation of community-based maternal health care services among women in Myanmar: a cross-sectional study. J Public Health. 2018.

23. Moller AB, Petzold M, Chou D, Say L. Early antenatal care visit: a systematic analysis of regional and global levels and trends of coverage from 1990 to 2013. Lancet Glob Health. 2017;5(10):e977e83. 